\title{
PENDEKATAN ANALISIS JALUR (PATH ANALYSIS) PADA KINERJA GURU MATEMATIKA SMA NEGERI DI KOTA MAKASSAR DITINJAU DARI MOTIVASI KERJA, KOMITMEN KERJA, KOMPETENSI PROFESIONAL DAN KOMPETENSI PEDAGOGIK
}

\author{
St. Nur Humaih Halim ${ }^{\mathrm{i}}$, Suwardi Anas ${ }^{\mathrm{ii}}$
}

\author{
iProdi Matematika FKIP UNISMUH Makassar,irahumairah08@gmail.com \\ ${ }^{\text {ii }}$ Prodi Matematika FMIPA UNM
}

\begin{abstract}
ABSTRAK, Penelitian ini bertujuan untuk mengetahui seberapa besar pengaruh motivasi kerja terhadap kinerja guru matematika baik secara langsung maupun tidak langsung melalui komitmen kerja, kompetensi profesional dan kompetensi pedagogik guru matematika SMA Negeri di kota Makassar.

Jenis penelitian ini adalah ex-post facto. Adapun jumlah sampel yang terkumpul melalui stratified purposive random sampling sebanyak 85 orang. Teknik pengumpulan data menggunakan angket komitmen kerja, angket motivasi kerja, tes kompetensi profesional, tes kompetensi pedagogik, dan dokumentasi kinerja guru matematika. Data hasil penelitian dianalisis dengan analisis statistika deskriptif dan analisis jalur (path analysis).

Hasil penelitian menunjukkan bahwa: Motivasi kerja secara langsung berpengaruh positif dan tidak signifikan terhadap kinerja guru matematika SMA Negeri di Kota Makassar. Sedangkan secara tidak langsung, motivasi kerja berpengaruh positif dan signifikan terhadap kinerja guru matematika SMA Negeri di Kota Makassar melalui komitmen kerja. Selanjutnya, motivasi kerja berpengaruh negatif dan signifikan terhadap kinerja guru matematika SMA Negeri di Kota Makassar melalui kompetensi profesional. Selain itu, motivasi kerja berpengaruh negatif dan tidak signifikan terhadap kinerja guru matematika SMA Negeri di Kota Makassar melalui komitmen kerja kemudian kompetensi profesional. Kemudian, motivasi kerja berpengaruh positif dan tidak signifikan terhadap kinerja guru matematika SMA Negeri di Kota Makassar melalui kompetensi pedagogik. Selanjutnya, motivasi kerja berpengaruh negatif dan tidak signifikan terhadap kinerja guru matematika SMA Negeri di Kota Makassar melalui komitmen kerja kemudian kompetensi pedagogik.
\end{abstract}

Kata Kunci: Analisis Jalur, Motivasi Kerja, Komitmen Kerja, Kompetensi Profesional, Kompetensi Pedagogik, Kinerja Guru

\section{PENDAHULUAN}

Mutu pendidikan yang baik sangat dipengaruhi oleh kinerja guru dalam melaksanakan tugasnya sehingga kinerja guru menjadi tuntutan penting untuk mencapai keberhasilan pendidikan. Secara umum mutu pendidikan yang baik menjadi tolok ukur bagi keberhasilan kinerja yang ditunjukkan guru.

Selain itu, lahirnya Undang-Undang Guru dan Dosen menuntut sosok guru yang berkualifikasi, berkompetensi, dan bersertifikasi. Jadi, kinerja guru pun dapat dilihat pada kualitas kerja yang dilakukan berkaitan dengan kegiatan belajar mengajar yang mengacu pada kompetensi guru. Guru harus menguasai beragam perspektif dan strategi, dan harus bisa mengaplikasikannya secara fleksibel. Hal ini membutuhkan dua hal yang utama: 1) pengetahuan dan keahlian profesional dan 2) komitmen dan motivasi. Pengetahuan dan keahlian profesional yang dimaksud adalah penguasaan materi pelajaran dan keahlian atau keterampilan mengajar yang baik [6]. Hal ini berarti, guru yang memiliki kinerja yang baik, tidak hanya sekedar memiliki penguasaan materi pelajaran atau kompetensi profesional, serta keahlian mengajar atau kompetensi pedagogik, namun juga membutuhkan komitmen dan motivasi.

Rendahnya kinerja guru SMA dapat dilihat dari hasil uji kompetensi yang diikutinya, untuk hasil uji kompetensi guru kota Makassar berdasarkan hasil wawancara kepala Dinas Pendidikan Kota Makassar, Mahmud BM menyatakan bahwa separuh dari 5.240 guru bersertifikasi di Kota Makassar tidak dapat memenuhi standar kompetensi guru nasional yang ditetapkan dinas pendidikan dan pemerintah pusat, yaitu minimal 70 poin. Namun, nilai yang diperoleh Makassar hanya 30, 40, sampai 50 poin [13]. Hasil ini menunjukkan bahwa kompetensi guru di kota Makassar tergolong rendah dan dapat menjadi indikasi akan rendahnya kinerja guru di kota Makassar. 
Dari kenyataan di atas, tampaknya perlu adanya suatu pengkajian secara terarah dan sistematis tentang variabel-variabel yang bersumber dari dalam diri guru itu sendiri, yang secara teoritis mempengaruhi kinerja guru matematika.Mengingat cukup banyak variabel yang bersumber dari dalam diri guru yang berpengaruh terhadap kinerja guru matematika dan keterbatasan peneliti dalam berbagai hal seperti biaya, waktu, dan kemampuan, maka peneliti membatasi diri dalam kajiannya, yaitu hanya memperhatikan pengaruh variabel komitmen kerja, variabel motivasi kerja, variabel kompetensi profesional dan variabel kompetensi pedagogik terhadap kinerja guru khususnya guru mata pelajaran matematika SMA Negeri di kota Makassar.

\section{TINJAUAN PUSTAKA}

\section{Kinerja Guru Matematika}

Bernardian \& Russell menyatakan bahwa kinerja adalah catatan mengenai outcome yang dihasilkan dari suatu aktivitas tertentu, selama kurun waktu tertentu pula [8]. Sedangkan menurut Hasibuan menyatakan bahwa kinerja adalah suatu hasil kerja yang dicapai seseorang dalam melaksanakan tugas-tugas yang dibebankan kepadanya yang didasarkan atas kecakapan, pengalaman, dan kesungguhan [4].

Berdasarkan pendapat-pendapat tersebut, yang dimaksud dengan kinerja guru matematika adalah intensitas menyeluruh dari kemampuan dan keberhasilan seorang guru matematika dalam melaksanakan tugas profesinya.

\section{Motivasi Kerja}

Berbicara mengenai motivasi berarti hal ini identik dengan proses psikologis. Sebagaimana yang dinyatakan oleh Wahdjosumidjo bahwa motivasi merupakan suatu proses psikologis yang mencerminkan interaksi antar sikap, kebutuhan, persepsi dan keputusan yang terjadi dalam diri seseorang [7]. Sedangkan menurut Sinclair, Dowson \& McInerney, motivasi adalah apa yang memulai, menopang dan berpusat pada perilaku. Jika motivasi ini dikaitkan dengan kinerja seseorang, maka motivasi yang dimaksud dalam hal ini adalah motivasi kerja atau motivasi berprestasi [2].

Martoyo mengemukakan bahwa motivasi kerja adalah suatu dorongan atau semangat kerja dalam menyelesaikan tugas-tugas untuk mencapai tujuan. Lebih lanjut dijelaskan pula faktor-faktor yang dapat mempengaruhi motivasi kerja yaitu: atasan, rekan, sarana fisik, kebijaksanaan dan peraturan, imbalan jasa uang, jenis pekerjaan dan tantangan [9].

Dari beberapa pandangan mengenai motivasi kerja yang telah diuraikan, maka dapat disimpulkan bahwa motivasi kerja adalah dorongan yang bersumber baik dari dalam dan dari luar diri seseorang yang menimbulkan suatu tindakan untuk memenuhi kebutuhannya.

\section{Komitmen Kerja}

Dalam bahasa Inggris, kata "komitmen" diterjemahkan dari kata "commitment" yang berarti perjanjian untuk melakukan sesuatu [3]. Dari pengertian tersebut, dapat diinterpretasikan bahwa komitmen merupakan kontrak atau perjanjian (keterikatan) baik terhadap diri sendiri atau terhadap organisasi untuk melaksanakan sesuatu. Sedangkan menurut Lee, Casrwell,\& Allen komitmen kerja sebagai hubungan psikologis antara seseorang dengan pekerjaannya yang didasarkan pada reaksi afektif terhadap pekerjaan tersebut [1].

Dari beberapa definisi mengenai komitmen kerja yang telah diuraikan di atas, maka dapat disimpulkan bahwa komitmen kerja adalah keterikatan seseorang terhadap pekerjaannya yang merefleksikan tingkat keterlibatan orang tersebut dalam melaksanakan perannya secara efektif serta keinginan untuk tetap menjadi bagian dari profesinya dalam organisasi tertentu.

\section{Kompetensi Profesional dan Pedagogik}

Kata kompetensi berasal dari bahasa Inggris, yaitu competence artinya kemampuan untuk melakukan sesuatu dengan baik [4]. Menurut Dharma bahwa terdapat lima karakteristik pembentuk kompetensi, yaitu watak, motif, konsep diri, pengetahuan dan keterampilan [5]. Adapun definisi kompetensi profesional yang dimaksud dalam penelitian ini adalah pengetahuan seorang guru mengenai 
materi pembelajaran secara luas dan mendalam untuk menunjang guru dalam melaksanakan tugas keguruannya. Sedangkan, kompetensi pedagogik adalah pengetahuan seorang guru dalam mengelola pembelajaran peserta didik dengan tujuan agar anak mampu secara mandiri menyelesaikan permasalahan yang dihadapinya.

\section{METODOLOGI}

Penelitian ini tergolong jenis penelitian $e x$ post facto yang bersifat kausalitas, yakni untuk menerangkan adanya hubungan sebab akibat antar variabel dan menguji hipotesis yang telah dirumuskan sebelumnya antara motivasi kerja, komitmen kerja, kompetensi profesional dan kompetensi pedagogik terhadap kinerja guru matematika. Metode pengambilan sampel yang digunakan untuk memperoleh sampel acak dan dapat merepresentasikan karakteristik populasi adalah menggunakan stratified purposive random sampling, sehingga jumlah sampel yang terambil dari populasi adalah 85 orang guru.

Langkah- langkah dalam proses penelitian ini adalah:

1. Mengembangkan instrumen penelitian melalui langkah-langkah berikut: (a) menentukan dimensi/indikator variabel penelitian, (b) menyusun kisi-kisi instrumen, (c) membuat butir instrumen, (d) melakukan validasi pakar, (e) melakukan uji coba instrumen, (7) melakukan uji validitas butir, dan (8) menentukan koefisien reliabilitas instrumen.

2. Memberikan instrumen yang telah dikembangkan kepada guru matematika yang merupakan sampel penelitian, yaitu terdiri dari angket motivasi kerja, angket komitmen kerja, tes kompetensi profesional dan tes kompetensi pedagogik.

3. Menganalisis data hasil penelitian dengan menggunakan teknik analisis deskriptif untuk mendeskripsikan serta memberikan gambaran tentang data setiap variabel yang disajikan dalam bentuk tabel distribusi frekuensi dan diagram batang serta menafsirkan nilai mean, median, standar deviasi, variansi, skewness, kurtosis, nilai maksimum, dan nilai minimum. Untuk menggambarkan hasil analisis deskriptif masing-masing variabel yang diteliti dibandingkan dengan tabel kriteria.

4. Menganalisis data hasil penelitian dengan menggunakan teknik analisis inferensial yaitu analisis jalur. Hasil analisis jalur (path analysis) diperuntukkan untuk mengetahui pengaruh langsung (direct effect) dan tidak langsung (indirect effect) dari variabelvariabel dalam penelitian ini serta mengetahui signifikansi hubungan antar beberapa variabel yang diprediksi. Dengan kata lain, analisis jalur digunakan untuk menguji hipotesis penelitian yang telah dirumuskan. Selain itu, analisis jalur dapat digunakan untuk mengetahui besarnya kontribusi variabel bebas yang berpengaruh langsung maupun tidak langsung terhadap variabel terikat.

\section{PEMBAHASAN}

\section{Analisis Jalur (Path Analysis)}

Hasil dari analisis jalur dapat dilihat pada diagram alur dibawah ini berikut:

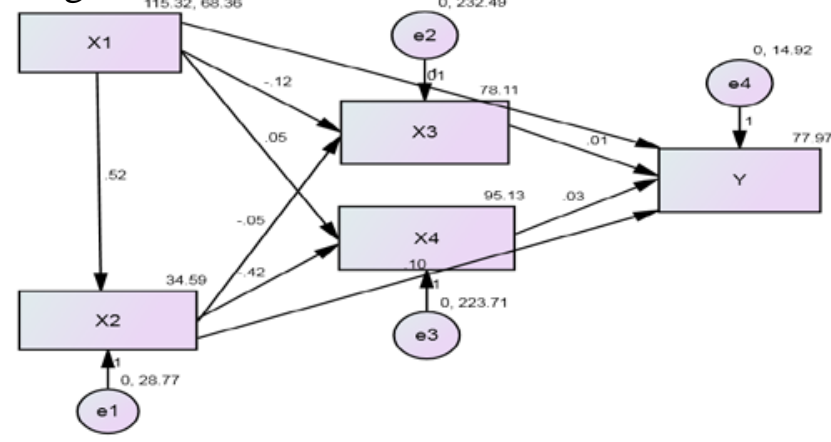

Keterangan:

$\longrightarrow=$ Hubungan kausal

$\mathrm{X}_{1} \quad=$ Motivasi kerja

$\mathrm{X}_{2} \quad=$ Komitmen kerja

$\mathrm{X}_{3} \quad=$ Kompetensi profesional guru

$\mathrm{X}_{4} \quad=$ Kompetensi pedagogik guru

$\mathrm{Y} \quad=$ Kinerja guru matematika

Koefisien jalur yang tertera pada diagram alur bukanlah yang terbakukan (unstandardized) sehingga untuk membandingkan antara koefisien yang satu dengan yang lainnya digunakan koefisien terbakukan (standardized coefficient)[10]. Berdasarkan hasil output Amos dapat disajikan koefisien jalur terbakukan yang dapat dilihat pada Tabel 1 berikut:

Tabel 1 Standardized Regression Weights 


\begin{tabular}{lllr}
\hline & & & Estimate \\
\hline X2 & $<---$ & X1 & 0,622 \\
X3 & $<---$ & X2 & $-0,020$ \\
X4 & $<---$ & X2 & $-0,188$ \\
X3 & $<---$ & X1 & $-0,067$ \\
X4 & $<---$ & X1 & 0,026 \\
$Y$ & $<---$ & X2 & 0,167 \\
$Y$ & $<---$ & X1 & 0,014 \\
$Y$ & $<---$ & X3 & 0,024 \\
$Y$ & $<---$ & X4 & 0,133 \\
\hline
\end{tabular}

Dari tabel 1 dapat ditentukan seberapa besar pengaruh langsung, pengaruh tidak langsung dan pengaruh total sebagaimana yang terlihat pada tabel 2 yang merupakan tabel dekomposisi kausalitas koefisien jalur.

Tabel 2 Dekomposisi dari Koefisien Jalur

\begin{tabular}{lcccccc}
\hline $\begin{array}{c}\text { Pengaruh } \\
\text { Peubah }\end{array}$ & $\mathrm{L}$ & & Melalui & & $\mathrm{TL}$ & Total \\
\cline { 1 - 3 } $\mathrm{X}_{2}$ ke & $-0,02$ & - & - & - & - & $-0,02$ \\
$\mathrm{X}_{3}$ & $-0,19$ & - & - & - & - & $-0,19$ \\
$\mathrm{X}_{2}$ ke & 0,17 & - & $-0,001$ & - & $-0,03$ & 0,14 \\
$\mathrm{X}_{4}$ & 0,62 & - & - & 0.025 & - & 0,62 \\
$\mathrm{X}_{2}$ ke & $-0,07$ & - & - & - & - & $-0,08$ \\
$\mathrm{Y}_{2}$ & 0,023 & 0,01 & - & - & 0,012 & $-0,10$ \\
$\mathrm{X}_{1}$ ke & 0,01 & - & $-0,002$ & - & $-0,12$ & 0,15 \\
$\mathrm{X}_{2}$ & 0,02 & 0,12 & - & 0,004 & 0,002 & 0,10 \\
$\mathrm{X}_{1}$ ke & 0,13 & - & 0,0003 & $-0,02$ & 0,09 & 0,02 \\
$\mathrm{X}_{3}$ & & 0,10 & - & - & - & 0,13 \\
$\mathrm{X}_{1}$ ke & & - & - & - & - & \\
$\mathrm{X}_{4}$ & & - & & & & \\
$\mathrm{X}_{1}$ ke & & & & & & \\
$\mathrm{Y}$ & & & & & & \\
$\mathrm{X}_{3}$ ke Y & & & & & & \\
$\mathrm{X}_{4}$ ke Y & & & & & & \\
\hline
\end{tabular}

Adapun besarnya kontribusi variabel bebas yang berpengaruh langsung terhadap variabel terikat dapat dicari melalui hasil pangkat koefisien jalurnya, sedangkan untuk mencari besarnya kontribusi variabel bebas yang secara tidak langsung berpengaruh terhadap variabel terikat dapat dicari melalui perkalian koefisien jalur yang terstandarisasi $(\beta)$ dengan koefisien korelasi (r) product moment untuk sebuah variabel bebas tertentu.

Tabel 3 Matriks Korelasi antar Variabel

\begin{tabular}{rrrrrr}
\hline & \multicolumn{1}{c}{ X1 } & X2 & X4 & X3 & Y \\
\hline X1 & 1,000 & & & & \\
X2 & 0,622 & 1,000 & & & \\
X4 & $-0,091$ & $-0,172$ & 1,000 & & \\
X3 & $-0,080$ & $-0,062$ & 0,635 & 1,000 & \\
Y & 0,104 & 0,151 & 0,118 & 0,097 & 1,000 \\
\hline
\end{tabular}

\section{Deskripsi Pengaruh Antar Variabel}

1. Pengaruh motivasi kerja terhadap kinerja guru matematika

Berdasarkan hasil pengujian pada Tabel 2 bahwa motivasi kerja berpengaruh positif terhadap kinerja guru matematika, dengan koefisien jalurnya sebesar 0,01 dan besarnya kontribusi sekitar 0,02\% dengan nilai $p=0,917$. Andaikan nilai $p$ digunakan sebagai fungsi keyakinan, maka diperoleh koefisien kepercayaan $1-p=0,083$, sehingga dapat disimpulkan bahwa hasil uji tersebut memiliki tingkat kepercayaan kurang dari 8,3\%. Tingkat kepercayaan tersebut dianggap sangat rendah dan tidak dapat ditolerir karena kurang dari 55\%. Hasil ini menunjukkan bahwa motivasi kerja memberikan pengaruh langsung yang positif dan tidak signifikan terhadap kinerja guru matematika.

Hasil penelitian yang menunjukkan bahwa motivasi kerja berpengaruh positif dan tidak signifikan terhadap kinerja guru relevan dengan hasil penelitian terdahulu yang menjelaskan bahwa guru di sekolah umum tidak termotivasi dengan baik sehingga dapat mempengaruhi kinerja mereka. Adanya ketidakseimbangan antara motivasi dan kinerja dapat dipengaruhi oleh lingkungan yang buruk, kondisi ketidakpuasan terhadap pekerjaan, kepemimpinan kepala sekolah yang buruk, dan hal lainnya [11].

Selain penelitian relevan di atas yang mendukung hasil penelitian ini, peneliti menduga adanya kemungkinan biasnya hasil penelitian ini dikarenakan tingginya skor kinerja guru matematika yang diperoleh dari hasil dokumentasi masing-masing sekolah yang menjadi lokasi penelitian, namun tidak diimbangi dengan skor motivasi kerja yang diperoleh dari hasil pengisian angket motivasi kerja oleh guru tersebut. Dari kenyataan yang peneliti temukan dilapangan, adanya ketidakseimbangan ini karena dipengaruhi oleh adanya kepentingan dari pihak sekolah, baik itu kepentingan dari guru yang bersangkutan maupun kepala sekolah sebagai stake holder. Kepentingan yang dimaksud disini adalah kepentingan terkait adanya pengusulan kenaikan pangkat bagi guru-guru dan wewenang kepala sekolah dalam memberikan penilaian yang dapat 
dipengaruhi oleh bagaimana kedekatan guru tersebut dengan kepala sekolah. Guru dengan hasil penilaian kinerja yang lebih rendah daripada tahun sebelumnya akan sulit untuk naik pangkat, tinggi rendahnya pangkat ini akan mempengaruhi tunjangan yang diperoleh oleh guru itu sendiri.

Dari uraian di atas, motivasi kerja memiliki pengaruh langsung positif dan tidak signifikan terhadap kinerja guru matematika atau dapat dikatakan motivasi kerja tidak serta merta memiliki pengaruh terhadap kinerja guru matematika.

2. Pengaruh motivasi kerja terhadap kinerja guru matematika melalui komitmen kerja, kompetensi profesional dan kompetensi pedagogik

a. Pengaruh motivasi kerja terhadap kinerja guru matematika melalui komitmen kerja

Pengaruh motivasi kerja terhadap kinerja guru matematika melalui komitmen kerja dapat dilihat pada Tabel 2 dengan koefisien jalurnya sebesar 0,10 dan besarnya kontribusi sekitar $1,1 \%$ dengan nilai $\mathrm{p}=0,019<0,05$ yang berarti signifikan. Meskipun demikian, hasil uji ini menunjukkan hubungan yang lemah antara motivasi kerja terhadap kinerja guru melalui komitmen kerja. Hasil ini dikarenakan hubungan komitmen kerja terhadap kinerja guru juga lemah, yaitu berada pada tingkat kepercayaan sekitar $77 \%$.

b. Pengaruh motivasi kerja terhadap kinerja guru matematika melalui kompetensi profesional

Pengaruh motivasi kerja terhadap kinerja guru matematika melalui kompetensi profesional dapat dilihat pada Tabel 2 dengan koefisien jalurnya sebesar -0,002 dan besarnya kontribusi sekitar 0,0004\% dengan nilai $\mathrm{p}=0,402$. Andaikan nilai $p$ digunakan sebagai fungsi keyakinan, maka diperoleh koefisien kepercayaan $1-p=0,598$, sehingga dapat disimpulkan bahwa hasil uji tersebut memiliki tingkat kepercayaan kurang dari 60\%. Tingkat kepercayaan tersebut masih dapat ditolerir karena lebih dari 55\%. Hasil ini menunjukkan bahwa motivasi kerja memberikan sumbangan atau pengaruh langsung yang negatif dan signifikan terhadap kinerja guru matematika melalui kompetensi profesional pada taraf kepercayaan 55\%. Adapun pengaruh motivasi kerja terhadap kinerja guru matematika melalui komitmen kerja kemudian kompetensi profesional dapat dilihat pada Tabel 2 dengan koefisien jalurnya sebesar $-0,0003$ dan besarnya kontribusi sekitar $0,00001 \%$ dengan nilai $\mathrm{p}=$ 0,497 diperoleh koefisien kepercayaan $1-p=$ 0,503 , sehingga dapat disimpulkan bahwa hasil uji tersebut memiliki tingkat kepercayaan kurang dari 50,3\%. Tingkat kepercayaan tersebut dianggap sangat rendah dan tidak dapat ditolerir karena kurang dari 55\%. Hasil ini menunjukkan bahwa motivasi kerja memberikan sumbangan atau pengaruh langsung yang negatif dan tidak signifikan terhadap kinerja guru matematika melalui komitmen kerja kemudian kompetensi profesional. Hasil ini dikarenakan koefisien jalur motivasi kerja terhadap kompetensi profesional baik secara langsung maupun tidak langsung melalui komitmen kerja bernilai negatif.

c. Pengaruh motivasi kerja terhadap kinerja guru matematika melalui kompetensi pedagogik

Pengaruh motivasi kerja terhadap kinerja guru matematika melalui kompetensi pedagogik dapat dilihat pada Tabel 2 dengan koefisien jalurnya sebesar 0,004 dan besarnya kontribusi sekitar $0,002 \%$ dengan nilai $\mathrm{p}=0,459$ diperoleh koefisien kepercayaan $1-p=0,541$, sehingga dapat disimpulkan bahwa hasil uji tersebut memiliki tingkat kepercayaan sekitar 54\%. Tingkat kepercayaan tersebut dianggap sangat rendah dan tidak dapat ditolerir karena kurang dari 55\%. Hasil ini menunjukkan bahwa motivasi kerja memberikan sumbangan atau pengaruh langsung yang positif dan tidak signifikan terhadap kinerja guru matematika melalui kompetensi pedagogik. Hasil uji ini menunjukkan hubungan yang lemah antara motivasi kerja terhadap kinerja guru melalui kompetensi pedagogik. Hasil ini dikarenakan hubungan motivasi kerja terhadap kompetensi pedagogik juga lemah, yaitu berada pada tingkat kepercayaan sekitar 15,3\%.

Selanjutnya, pengaruh motivasi kerja terhadap kinerja guru matematika melalui komitmen kerja kemudian kompetensi pedagogik dapat dilihat pada Tabel 2 dengan koefisien jalurnya sebesar $-0,016$ dan besarnya kontribusi sekitar $0,03 \%$ dengan nilai $\mathrm{p}=0,470$ 
diperoleh koefisien kepercayaan $1-p=0,530$, sehingga dapat disimpulkan bahwa hasil uji tersebut memiliki tingkat kepercayaan sekitar 53\%. Tingkat kepercayaan tersebut dianggap sangat rendah dan tidak dapat ditolerir karena kurang dari 55\%. Hasil ini menunjukkan bahwa motivasi kerja memberikan pengaruh langsung yang negatif dan tidak signifikan terhadap kinerja guru matematika melalui komitmen kerja kemudian kompetensi pedagogik. Hasil uji ini menunjukkan hubungan yang lemah antara motivasi kerja terhadap kinerja guru melalui komitmen kerja kemudian kompetensi pedagogik. Hasil ini dikarenakan koefisien jalur motivasi kerja terhadap kompetensi pedagogik melalui komitmen kerja bernilai negatif. Jika koefisien jalur tersebut ditelusuri kembali maka hasil ini pada dasarnya diperoleh karena nilai koefisien jalur variabel komitmen kerja ke variabel kompetensi pedagogik yang negatif.

Hasil penelitian yang menunjukkan bahwa komitmen kerja tidak signifikan berpengaruh terhadap kinerja guru melalui kompetensi pedagogik relevan dengan hasil penelitian terdahulu yang menjelaskan bahwa hubungan antara komitmen dan kompetensi mengajar tidak signifikan. Jadi tidak ada hubungan antara komitmen dan kompetensi mengajar [12].

Dari uraian di atas, motivasi kerja memiliki pengaruh tidak signifikan terhadap kinerja guru matematika baik melalui kompetensi pedagogik, atau komitmen kerja kemudian kompetensi pedagogik.

\section{KESIMPULAN}

Hasil penelitian menunjukkan:

1. Sebagian besar guru matematika SMA Negeri di Kota Makassar memiliki motivasi kerja (MK), komitmen kerja (KK), kompetensi profesional (KP), dan kompetensi pedagogik (KD) berada dalam kategori sedang. Sedangkan untuk kinerja guru matematika (KG) berada dalam kategori baik.

2. Motivasi kerja $\left(\mathrm{X}_{1}\right)$ secara langsung berpengaruh positif dan tidak signifikan terhadap kinerja guru matematika SMA Negeri di Kota Makassar (Y) pada tingkat kepercayaan kurang dari 55\% dengan koefisien jalur sebesar 0,014. Sedangkan secara tidak langsung, motivasi kerja $\left(\mathrm{X}_{1}\right)$ berpengaruh positif dan signifikan terhadap kinerja guru matematika SMA Negeri di Kota Makassar (Y) melalui komitmen kerja $\left(\mathrm{X}_{2}\right)$ pada tingkat kepercayaan sekitar 98\% dengan koefisien jalur sebesar 0,104. Selanjutnya, motivasi kerja $\left(\mathrm{X}_{1}\right)$ berpengaruh negatif dan signifikan terhadap kinerja guru matematika SMA Negeri di Kota Makassar (Y) melalui kompetensi profesional $\left(\mathrm{X}_{3}\right)$ yang berada pada tingkat kepercayaan kurang dari 60\% dengan koefisien jalur sebesar-0,002. Selain itu, motivasi kerja $\left(\mathrm{X}_{1}\right)$ berpengaruh negatif dan tidak signifikan terhadap kinerja guru matematika SMA Negeri di Kota Makassar (Y) melalui komitmen kerja $\left(\mathrm{X}_{2}\right)$ kemudian kompetensi profesional $\left(\mathrm{X}_{3}\right)$ yang berada pada tingkat kepercayaan kurang dari 55\% dengan koefisien jalur sebesar -0,0003. Kemudian, motivasi kerja $\left(\mathrm{X}_{1}\right)$ berpengaruh positif dan tidak signifikan terhadap kinerja guru matematika SMA Negeri di Kota Makassar (Y) melalui kompetensi pedagogik $\left(\mathrm{X}_{4}\right)$ yang berada pada tingkat kepercayaan kurang dari $55 \%$ dengan koefisien jalur sebesar 0,004. Selanjutnya, motivasi kerja $\left(\mathrm{X}_{1}\right)$ berpengaruh negatif dan tidak signifikan terhadap kinerja guru matematika SMA Negeri di Kota Makassar (Y) melalui komitmen kerja $\left(\mathrm{X}_{2}\right)$ kemudian kompetensi pedagogik $\left(\mathrm{X}_{4}\right)$ yang berada pada tingkat kepercayaan kurang dari 55\% dengan koefisien jalur sebesar -0,016.

\section{DAFTAR PUSTAKA}

[1] Blau, Gary. 2003. Testing for A FourDimensional Structure of Occupational Commitment. Journal of Occupational and Organizational Psychology, 76, 469-488.

[2] Canrinus, Esther T., et al. 2012. Selfefficacy, Job Satisfaction, Motivation and Commitment: Exploring the Relationships Between Indicators of Teachers' Professional Identity. Eur J Psychol Educ, 27, 115-132.

[3] Oxford (Learner's Pocket) Dictionary. 2008. UK: Oxford University Press.

[4] Palisungan, Daud M. 2011. Pengaruh Iklim Kerja dan Iklim Sekolah terhadap Kinerja Guru SMK di Kabupaten Tana Toraja. Tesis. Tidak diterbitkan. Program 
Pascasarjana Program Studi Administrasi Pendidikan Konsentrasi Manajemen Pendidikan Universitas Negeri Makassar.

[5] Riduwan \& Kuncoro, Engkos A. 2008. Cara Menggunakan dan Memaknai Analisis Jalur. Bandung: Alfabeta.

[6] Santrock, J.W. 2012. Psikologi Pendidikan Edisi 2. Jakarta: Kencana Prenada Media Group.

[7] Saydam, Gouzali. 2005. Manajemen Sumber Daya Manusia: Suatu Pendekatan Mikro. Jakarta: Kresna Prima Persada.

[8] Sedarmayanti. 2011. Manajemen Sumber Daya Manusia, Reformasi Birokrasi dan Manajemen Pegawai Negeri Sipil. Bandung: PT. Refika Aditama.

[9] Suwitra, I N.A. 2012. Determinasi Kompetensi Profesional, Motivasi Kerja, dan Konsep Diri Akademik Terhadap Kinerja Guru Pada Sekolah Menengah Atas Negeri di Kecamatan Karangasem. Artikel penelitian. Administrasi Pendidikan, Program Pascasarjana, Universitas Pendidikan Ganesha.

[10] Tiro, M. A., Sukarna, \& Aswi. 2010. Analisis Jalur. Makassar: Andira Karya Mandiri.

[11] Inayatullah, Atiya \& Jehangir, Palwasha. 2014. Teacher's Job Performance: The Role of Motivation (Online), (http://www.abstract.xlibx.com/apedagogy/129328-3-teachers-jobperformance-the-role-motivation-atiyainayatul.php, diakses pada tanggal 21 Juni 2015).

[12] Sukhla, Shasi. 2014. Teaching Competency, Professional Commitment and Job Satisfaction-A Study of Primary School Teachers. IOSR Journal of Research \& Method in Education (IOSR-JRME), eISSN: 2320-7388,p-ISSN: 2320-737X, 4(3) Ver. II, 44-64.

[13] Rasdiyanah. 2012. 3.000 Guru di Makassar Ujian Kompetensi Tahap II (Online), (hhttp://nasional.tempo.co/read/news/2012 /09/17/176429988/3-000-guru-dimakassar-ujian-kompetensi-tahap-ii, diakses pada tanggal 12 Mei 2014). 